\title{
カーボン等の難染性物質の迅速染色
}

宮坂和雄

\author{
(平成4年7月24日受理)
}

\section{Quick Dyeing of Substrates such as Carbons Being Hard to Dye}

\author{
Kazuo Miyasaka \\ Honorary Professor of Kyoritsu Women University, \\ 6-33 1-Chome, Itabashiku, Tokyo 174, Japan
}

A substrate being hard to dye can be easily dyed a desire color, by applying a special dyebath containing concentrated sulfuric acid. All inorganic and organic materials may be instantly dyed a desire color, so far as those having a greater surface area are concerned.

The substrates being most hard to dye such as carbon black, polypropylene, polyvinyl chloride, polyvinilidene chloride, etc., may be quickly dyed a beautiful color, by this dyeing process.

Insoluble coloring materials, such as vat and sulfur colors, or pigments, are the most suitable for this process. These can be applied as molecular solutions. Therefore, a beautiful color can be satisfactly developed. Also, this new dyeing process can be applied to soluble coloring materials. In this case, an organic acid is useful as a component in the dye bath.

A special dyebath consisting of concentrated sulfuric acid and with the regular amounts of surface active agent and organic solvent which have an emulsified state may be used effectively for quick dyeing on the most hard to dye. This special dyebath has a greater dye-accessibility for the substrates being hard to dye.

KEYWORDS: Quick dye, New dyeing process, Being to dye hard, Sulfuric acid dyebath

\section{1.はじめに}

宋・明・清時代に作られた松煙墨 ${ }^{1}{ }^{2}$, 青色の清光を放 つ古墨として，貴重品のように賞賛されている。最近はほ とんど入手が困難で, 稀少価值も加わって憧憬する作家が 跡を断たない。この古墨に匹敵する墨は, 現在では作り難 いとされている。

私は, 偶然に故渥美富峰画伯から青墨の研究開発を依頼 されて, 古墨を解剖し青光を放つ秘密について究明した。 その結果，数多くの示唆を得て中国の古墨に匹敵する製墨

共立女子大学名誉教授: 連絡先 7174 東京都板橋区常盤 台1-33-6
の基本を確立2)することに成功した。

墨色は, カーボン(すす・カーボンブラック)の粒子径・ ストラクチャー・その他の物理化学的構造に密接に関連し ている。だ，本質的にはカーボンの色に支配されてい る。したがって，カーボンの色が変化すれば，墨色にも鋭 敏に反映するのは当然である。このような想定でカーボン の染色について重点的に研究を行い, 不完全ながらも染色 の方法を見出した。

カーボンのように, 緻密な結晶組織で構成され, 染色の 対象となる官能基が極度に少なく, 染着座席も異常に乏し い難染性物質は数多く存在する。代表的なものは合成繊維 で，市ぐれた抗張力・弾性・耐労性を付与するために，高 度に結晶化した強勒な組織となっている。そこで，これら 
の合成繊維類は，必然的に難染性繊維としての特徴を示す ことになる。この事実は, 炭化水素を基体とするポりエチ レン・ポリプロピレン・ポリ塩化ビニル・ポリ塩化ビニリ デン・ポリフルオロエチレンなどに象徴されている。

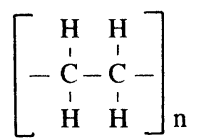

ポリエチレン
ポリプロピレン

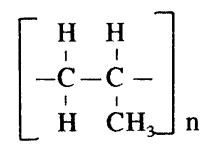

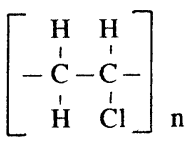

ポリ塩化ビニル

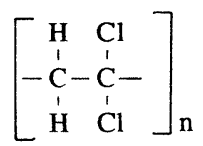

ポリ塩化ビニリデン

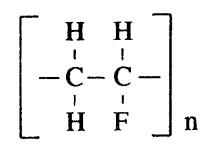

ポリフルオロエチレン
カーボン・その他の難染性物質の染色法の開発は, 時代 の要請に沿う重要な課題であると考えることができる。

\section{2. 標準的な染色過程 ${ }^{3)}$}

染色作用が物理的な要因に支配されるか, 化学的な機構 の下に進展するかに拘わらず，染色は先ず素材の表面に展 開される。この第一過程では染色剂が表面を包被して, 次 第にその濃度が高まっていく。染色作用が更に進めば第二 過程に発展する。この過程では染着の時間的進行と共に, 染色剂は組織の微細構造間隙内まで浸透して, 安定な染着 座席に到着する。このような染着が行われるかどうかは, 染色条件の適否に支配される。染着剂の分散状態・活性・ 浸透力・親和力・凝集力などは, 染着の優劣を支配する極 めて重要な要素である。

染色の最終過程(第三過程)では, 染色剂の分子を励起さ せて, 染着形態を最も安定なものに移行し, 完全な発色を 行うのが目的である。長時間の沸騰や蒸熱は, 第三過程の 進行を迅速にして, 耐光性・耐洗濯性・耐候性を高める手 段となる。

これらの過程を順調に進行させるには, 染色剂の特性に 対応して，染色条件を最適にするよう調節することが肝要 である。素材を浸漬して染色する方式では, 低温から徐々 に昇温して, 最高温度に保ちながら長時間処理するのが標 準である。

\section{3. 難染性物質の染色に対する考え方}

\section{1 難染性物質の染色の可能性}

合理的な染色を行うための必要条件は,

(1) 素材の微細構造間隙を自由に浸透できる程度ま

で，染色剂を微小に分散させなければならない。

(2) 同時に素材の結晶組織間隙をできるたけ大きく開
放させて, 染色剂の浸透を助長しながら, 安定強固な 染着を完成させる必要がある。

この条件が完全に満たされるときには, 難染性物質の染 色も可能になると考察される。

カーボンや炭化水素系の合成䋐維のように, 染着の対象 になる官能基も染着座席も皆無に等しい素材は, 従来の染 色加工を行う観念では, 染色は望み得ない。したがって染 色の手段は, 従来の踏襲から脱却した新たな構想に立脚し た新機軸を確立する必要がある。

\section{2 染斑の特性とその利用}

染色加工が合理的に行われるには, 第一過程と第二過程 の染色作用が, 同時に均衡しながら順調に進行することが 肝要である。もし，この均衡が保たれず，第一過程の染色 作用が先行し, 第二過程の染色作用が遅延すれば, 染色剂 は素材の表面上に重点的に染着することになる。このよう な染着が局部的に発生するのが, 染斑の典型的なものであ る。

染斑は, 染色初期の急激染着に基づくものである。染斑 の染着は意外に強固で溶脱しにくく、補正するのもはなは たしく困難である。それたけ強勒な染着形態を保有してい るとも言えよう。この特性を利用して, 殊更に染斑の発生 しやすいように条件を選定して染色を行えば，素材の表面 は染斑の均一な積層に覆われ, 堅牢な染着を完成すると推 定される。特に, 染斑を発生しやすい染着力の強大な高分 子染色剂, 例えば樎合多環染料・含金属高分子顔料などを 用い, 染斑の発生を助長するために強酸性の染浴を利用す れば，急激な染着作用が加速して短時間内に均一な染斑が 発生し，すぐれた耐光性・耐洗濯性・耐候性を表すことが 期待できそうである。

私が開発したカーボン・その他の難染性物質を染色する 方法4) は, 染斑の特性を利用し, 素材の表面を均一な染斑 で包被して，堅牢な染着を完成させるのが基本である。

\section{3 染色剂分子の分散}

3.1でも述べたように，すぐれた色相に染色するには， 染色剂分子の高度な分散と, 素材の組織内部への絶妙な浸 透と, 安定強固な染着が必須の条件であう。しかし, 堅固 な結晶組織で構成され, 結晶間隙は極度に小さく, 染色の 対象になる官能基も染着座席も皆無に等しいカーボン・そ の他の難染性物質を染色するには，極度に励起された染色 剂分子の強大な染着力に待つほかはない。

このためには，染色剤を分子溶液として応用すると共 に，苛酷な条件下で処理し，可能な限り結晶間隙を開放さ せて，染色剤分子の浸透を容易にしなければならない。し かも, 染色剂は最高の耐光性・耐洗濯性・耐候性を示すも のに限られる。

低温で生成する炭化物は, 有機化学的には縮合多環化合 
C.I. Pigment Blue 15

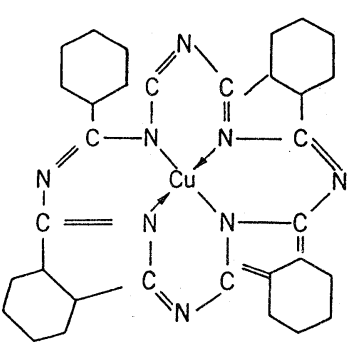

C.I. Vat Yellow 2

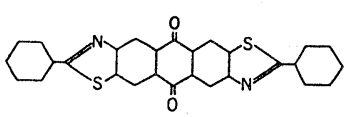

C.I. Vat Red I<smiles>CC1CC(Cl)CC2SC(=C3SC4CC(Cl)CC(C)C4C3=O)C(=O)C12</smiles>

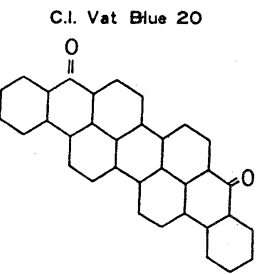

C.I. Pigment Green 36

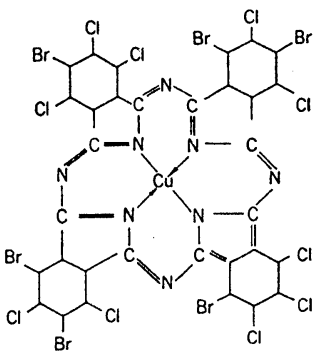

C.I. Vat Orange 2

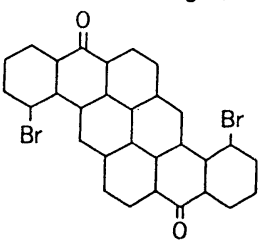

C.I. Vat Violet I
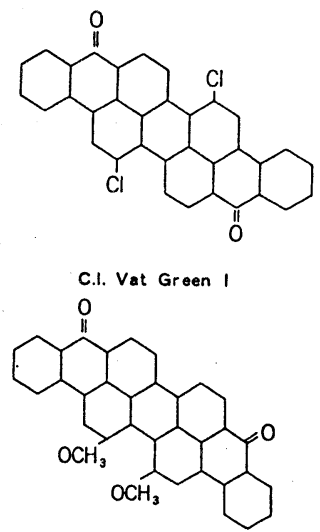

Fig.1 Exsample of dyestuffs

物であると考えられる。熱分解温度の上昇に伴って生成す る高度の炭化物は, 著しく縮合度の高まったものとなる。 このような高次の構造5に通ずる構造組織を有する染色剂 は，カーボンに親和しやすい特性を持つように思われる。 このような観点から，Fig.1に示すような縮合多環染料・ 建染め染料・含金属高分子顔料などは，染色剂として最適 と考えられる。しかし，これらの染色剂を分子溶液とする には，多くの困難を伴なう。

ここに注目すべきは，大部分の染色剂は濃硫酸に溶解し て，安定な分子溶液になることである。高温の濃硫酸には 縮合多環染料・建染好染料 - 硫化染料 ·含金属高分子顔料 など，いずれも容易に溶解 して分子溶液を形成する。こ の溶液を応用すれば，難染性物質の染色に必須の条件は完 全に満たすことができる。

私が開発した物理化学的染色加工法 ${ }^{7)}$ の特徵は, 最適な 染色剂の濃硫酸溶液を用いて，難染性物質を処理して染色 を行い，後処理を行って染着を強固にして，所望の堅牢度 を付与することである。

\section{4 硫酸染浴の作用}

最適な建染め染料・縮合多環染料などを用いても，アル カリと還元剤からなる染浴では，濃厚にして染着力を極度 に高めても，カーボンブラック・その他の難染性物質の染 色は困難である。これらの素材の染色は酸性浴に限られ， 特に硫酸染浴が好適である。

硫酸染浴の特徴は，極性・非極性染色剂を問わず分子溶 液を形成し，絶妙な浸透力と強大な染着力を発揮すること である。

高温の硫酸染浴は，カーボンの網平面に影響を与えず に, 平面間の距離を開いて染色剂分子の浸透を助長すると 推定される。一方, 染色剂分子の染着は化学的な要因に基 づくものは少なく，主に物理的なもので，層状構造の間隙 にも定着すると想像される。そこで, 高分子縮合多環染料 ·含金属高分子顔料などの硫酸溶液は, 絶大な染着力を示 し，この染浴に素材を浸漬すれば，その種類に関係なく， 急激な染着作用を発現して, 瞬間的に表層に染着する。こ の染着力は，比類ないほど強烈である。染着量は予想外に 少ないが，使用した染色剂に特有の色相を反映する。

\section{5 染色条件の選び方}

詳細に観察すれば，素材の種類・表面の物理化学的構造 ·粒子径・比容・ストラクチャーなどの違いに基づいて, 染着量・色相などに微妙な差が認められる。一般に小粒子 径のカーボンほど染着が強固に行われ，洗浄による脱落量 が少ないようである。概して揮発成分・酸化物・官能基に 富むカーボンほど，染色性がすぐれている。

ストラクチャーも染色性と密接に関連する。高分子有機 物の熱分解生成物を自然に沈降させる古式の方法で捕集し たランプブラック ${ }^{8)}$ は, 粒子が大きく表面積は小さいが, 揮発成分・酸化物・官能基に富み，染浴に親和して染色が 順調に行われる。比容の大小も染色性に大きく影響する。 比容の小さいカーボンは, 粒子相互が接着しやすく, 集合 して団粒子になりやすいので好ましくない。特に，表面が 円滑で結晶性の高いものは, 染色剂分子の浸透が困難で安 定に染着しにくい欠点を伴なう。

すぐれた染色結果を得るためには，適切な染色剂を厳選 し，染色条件を合理的に調整しなければならない。素材の 場合と同様に, 染色剂もその分子量·構造·官能基の種類 や数・結合の位置 - 不飽和結合の数 - その他の要因に基づ いて，それぞれに適合する条件下で染色することが必要で ある。概して一般染色法に適用される条件の市べては，硫 酸染浴にも共通すると考えるべきである。建染め染料に 
は，IN型・IW型・IK型がある9が，これらは染浴の組成も 染色温度も異なる。したがって，それぞれの染料に固有な 特性に最も適するように染色条件を巧みに調整して，初め て期待の色相・堅牢度が現れることを銘記すべきである。

\section{4. 染色の実例}

\section{1 カーボンの染色}

\subsection{1 染浴の作成}

染浴は所望の色相・濃度・堅牢度などに応じて，染色剤 の使用量を適宜に加減して作成する。素材であるカーボン および染色剂の種類によって, 染浴の濃度にはそれぞれ一 定の限界があり, 染色剂の使用量は, この限界以内に止め ることが必要である。この限界を無視して，多量の染色剂 を用いるときには，安定な染着形態に移行しにくく，洗浄 や機械的作用によって脱落しやすい欠点を伴なう。染色剂 使用の濃度限界は，染色剂の種類によって相違するが， カーボンの重量に対し5\%以下にするのが目安である。

染浴は，できる限り浴比(染色剂と溶解剂の容量比)を小 さくすることが望ましい。また，組成分として硫酸塩・そ の他の無機酸塩を混和すれば，染色剂分子の浸透を助長 し，染着量を増加するのに役立つ。酢酸ソーダ・その他の 有機酸塩は, 染浴の酸性を緩衝し, 硫酸の作用を緩和す る。同時に結晶組織の間隙に，染色剂分子の拡散するのを 助け，染色の明度を高めるのに効果的である。

染浴は所用量の染色剂に, 少量のロート油を加えて均一 に混和し，濃硫酸を加えて徐々に加熱して作成する。昇温 するにつれて, 分散している染色剤は次第に溶解し, 懸濁 液は半透明になる。この温度は, 使用玄る染色剂の種類に よって異なるが， $50 \sim 80^{\circ} \mathrm{C}$ 範囲内のものが大部分であ る。ただし，含金属高分子顔料のように溶けにくいもの

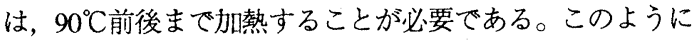
して作成された染浴は，低温に冷却しても，分子溶液状態 が安定に保たれる。しかし，カーボンを染色するには，で きるだけ高温に保つことが望ましい。

\section{1 .2 染色の工程}

染色剂・助剤・浸透剤などで組成される高温染浴に， カーボンを徐々に加えて均一に混和する。染浴は液量が少 ないため，カーボンを混和すると，直ちに泥状化する。染 着は短時間に完了すると思われるが，その徵候はいささか も見られない。この状態では, 硫酸染浴がカーボン粒子を 均一に包容していると考えられる。本質的な染着作用は, 続いて行う水と混和する過程で進行する。

泥状々態の高温染浴を放冷し，室温付近まで泠却した 後, 多量の水中に混和する。このとき濃硫酸と水が反応し て, 急激に発熱して沸騰し多量の水蒸気を発生しながら, カーボンが結晶化して析出する。この激烈な発熱や泡沸,
擋動や衝撃などの作用によって，染色剤の分子は異常に高 いエネルギーを与えられて励起する。同時にカーボンの結 晶組織の間隙や層状間隙が極度に開放する。これらの要因 の相乗効果によって，染着形態が著しく安定化すると思わ れる。染色剂の使用限界濃度内では, 染色剂は完全に収着 され, 染色されたカーボンは速かに器底に沈んで, 上澄液 は茶褐色を带びて澄明になる。

染色したカーボンは濾別・洗浄した後，アンモニア水を 加えて残存する硫酸を完全に中和し，十分に水洗する。さ らに脱水・乾燥した後, 粉砕して篩分けを行って, 微粒子 として補集する。

レジンフィニッシュ・熱固定処理などは, 染色カーボン の耐摩擦性を改良する効果が大きい。しかし，膠・ゼラチ ン・樹脂などの素材からなる製品に応用する場合には，そ の必要はない。

\subsection{3 畺色の分析}

Fig.2は墨色を分光々度計を用いて測色した結果》を示し ている。(a)は明時代に造られた著名な古墨の代表的なも のである。青色の清光を放つことが特記に值する。(b)は 染色剂を異にする同心゙組成の硫酸染浴中で, 同一条件で処 理したカーボンで製墨した試墨の墨色である。

Fig.2は，著名な中国古墨の墨色も，試墨の墨色も，ほ とんど同じであることを示している。このように，染色 カーボンを使用すれば，中国の著名な古墨に匹敵する墨が 容易に得られる。また墨色をある程度まで，希望どおりに 変えることができ, 墨芸の新分野の開拓に寄与すると思わ れる。
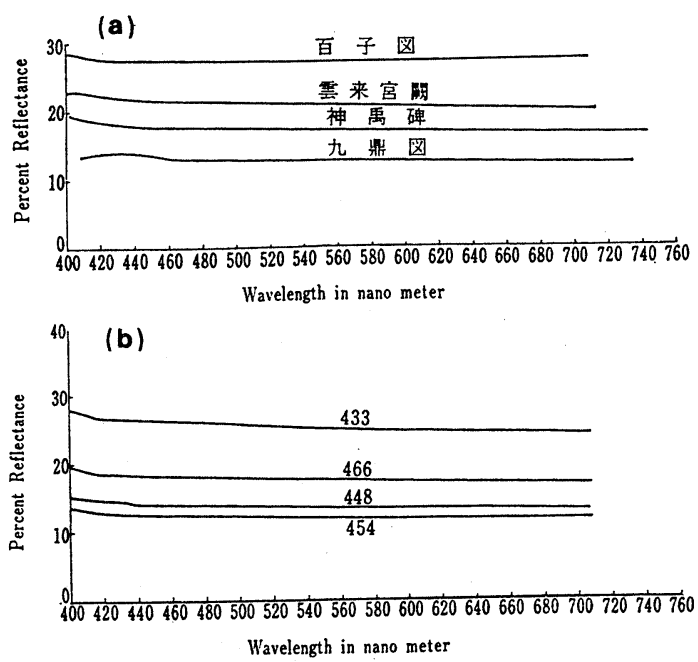

Fig.2 Dispersion of light reflectance from SUMI.

(a) representative chinese old-SUMI.

(b) SUMI made from dyed carbon. 


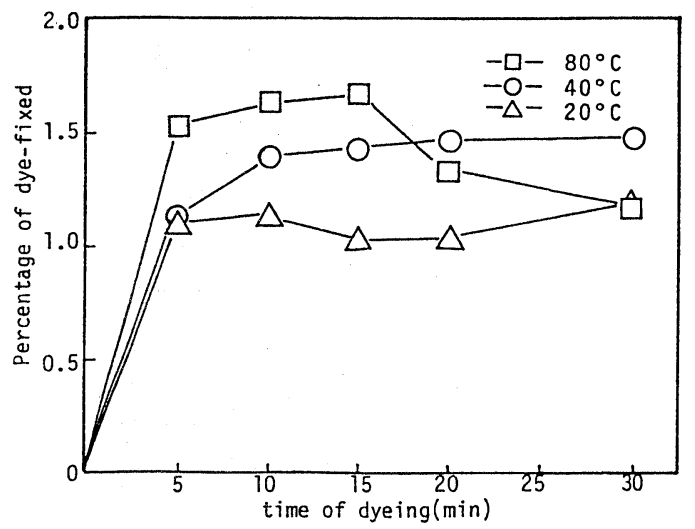

Fig.3 Effect of temperature on C.I.Vat Violet $2 \mathrm{R}$ dyebath to polypropylene dyeing.

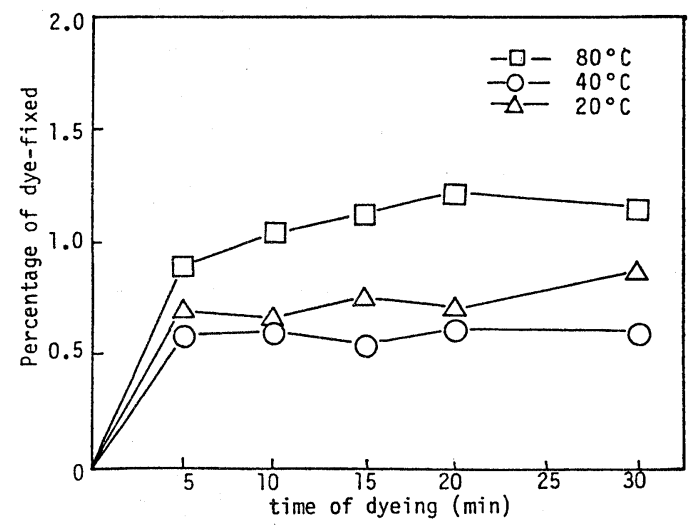

Fig.4 Effect of temperature on C.I.Vat Yellow GCN dyebath to polypropylene dyeing.

\section{2 ポリプロピレンの染色}

\section{2 .1 試染の方法}

精製した染料 $0.3 \mathrm{~g}$ にロート油 1 滴を加えて混和した後, 濃硫酸 $20 \mathrm{ml}$ 加え, $95^{\circ} \mathrm{C}$ で10分加熱して, 染料を完全に 溶解する。この溶液を $40^{\circ} \mathrm{C}$ に放冷し, トリクロロエチレン $1.7 \mathrm{ml}$, 非イオン活性剂のO/W型 $0.8 \mathrm{ml}, \mathrm{W} / \mathrm{O}$ 型 $0.4 \mathrm{ml}$ を混和 して作成した乳化剂を加え，浴比1:50として染浴を作成し た。

ここに使用する非極性溶剂(トリクロロエチレン)は，ポ リプロピレンの結晶間隙を開き，染料分子を組織内部に浸 透させるためのものである。非イオン活性剤は, 非極性溶 剂を乳化分散して染浴に対する親和性を高め, その特性を 発揚させるために役立つ。

この染浴にポリプロピレンーニットの精製試料 $0.4 \mathrm{~g}$ を浸 漬し，各種の温度・時間で染色した。染色物はビーカーの 側壁に10分間付着させて放冷する。この試料を $40^{\circ} \mathrm{C}$ 亜硝 酸ソーダ $1 \%$ 溶液 $20 \mathrm{ml}$ 中に 10 分間浸漬して酸化し，完全に
発色させて十分に水洗する。続いてアンモニア水 $0.2 \%$ 液, $20 \mathrm{ml}$ に浸漬して完全に中和し，水洗を行って乾燥した。

染料は, IN型のC.I. Vat Violet 2R, IW型のC.I. Vat Yellow GCNを使用した。

\section{2 .2 染善率の測定}

染色試料を $95 \%$ 硫酸 $50 \mathrm{ml}$ 用い, $95^{\circ} \mathrm{C} て ゙$ 処理して試料に 染着した染料を完全に溶解する。この溶液に $1 \%$ のデスパ ゾール液を加え，硫酸の濃度が正確に $2 \%$ にるように調 整する。この操作によって, 溶解状態の染料か酸化して発 色し, 微粒子に分散し, 均一なコロイド状を呈する。これ を直ちに分光々度計に掛けて透過率を測定し, 予め作成し た検量線に基づいて，その濃度を計算して染着率を求めた。

\section{2 .3 試染結果}

\section{(1) 染着率と染色温度 - 時間の関係 ${ }^{10}$}

Fig.3,4は，染色の時間的進行に伴なう染着率の変化を示 している。この曲線の形態は, IN型のC.I. VatViolet $2 \mathrm{R}$ と IW型のC.I. Vat Yellow GCNでは，非常に異なっている。 染着率は，いずれも高温で染色するほど増加する点では共 通している。しかし, IN型のC.I. Vat Violet 2Rの染着率 ははるかに高く, 最大の染着率に達する時間も短い。最大 の染着率は, Vat Violet 2R では1.68\%, 時間は15分程度 である。一方，Vat Yellow GCNでは，それぞれ1.22\%， 20分程度である。したがって, IN型のC.I. Vat Violet 2R は, IW型のC.I. Vat Yellow GCN に比べ, 短時間で $40 \%$ 程度も多く染着することになる。

試染の結果は明らかに，硫酸染浴を応用する迅速染色に は，高温で染色するIN型のVat染料が適することを物語っ ている。

(2) 溶剤の種類と染着率の関係 ${ }^{10)}$

Fig.5-(a),(b)は，CI Vat Violet 2R の硫酸染浴に，テト ラクロロエチレンやトリクロロエチレンの乳化液を加え, 試染を行った結果である。

この結果は明らかに，次の事実を示している。

(1) 乳化剂を加えて染色すれば，染着率が目立って増 加する。

(2) 染色温度が高温になるほど，高い染着率を示す。

(3) 染色時間の影響は少なく, 概ね10分程度で染着率 が最大に達し，時間を延長してもほとんど変らない。

(4)トリクロロエチレンの乳化液は，テトラクロロエ チレンの乳化液より助染効果が劣る。

\section{(3) 乳化液の組成と染着率の関係 ${ }^{10)}$}

Table 1に示す組成の乳化液を用い, Table 2の条件で試 染を実施した。結果をFig.6-(a)〜(d)に示す。

これより，以下の事実を確認することができる。

(1) 乳化液の助染効果は，Aが最もすぐれ，CはAより やや劣り，Dは相当に少る。Bは助染効果をほとんど示 

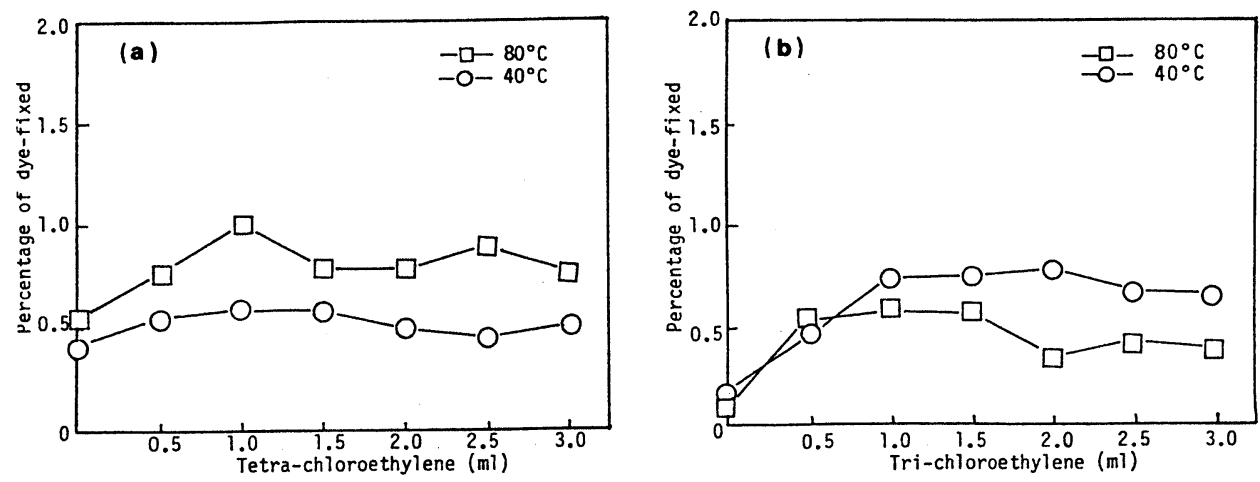

Fig.5 Effect of emulsified state of tetra-chloroethylene(a) and tri-chloroethylene(b) for dye-fixation to polypropylene dyeing.

Table 1 Composition of emulsions (ml)

\begin{tabular}{lrrrr}
\hline \multicolumn{1}{c}{ Component } & A & B & C & D \\
\hline Tetra-chloroethylene & 16.3 & 3.8 & 33.8 & 38.8 \\
Rote oil & 2.5 & 0.5 & 2.5 & 2.5 \\
Nonion active detergent W/O type & 4.2 & 1.9 & 2.5 & 2.5 \\
Nonion active detergent O/W type & 2.1 & 2.1 & 3.8 & 3.8 \\
Water & 25.0 & 43.0 & 25.0 & 25.0 \\
\hline
\end{tabular}
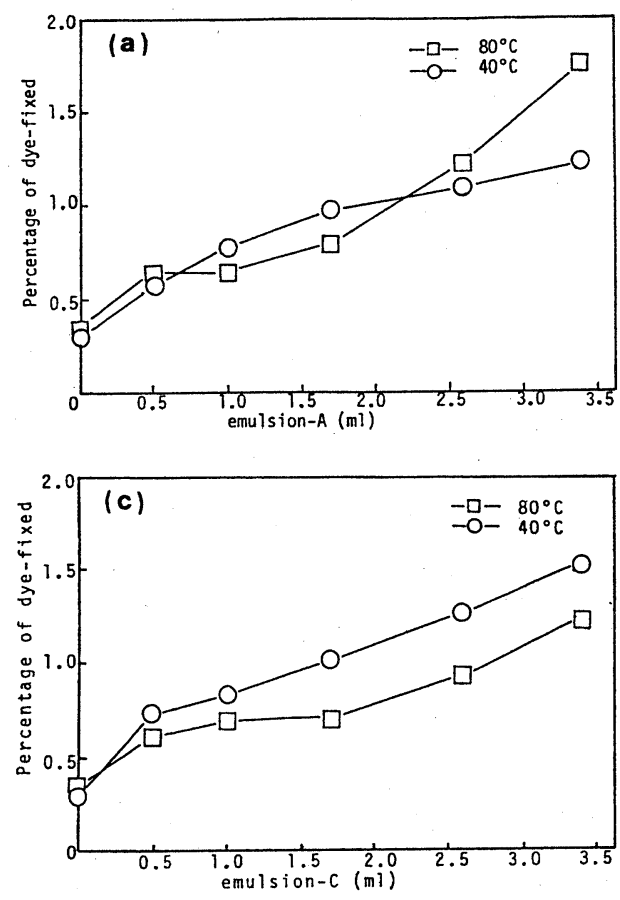

Table 2 Composition of dyebath and condition of dyeing

\begin{tabular}{lrrrrr}
\hline $\begin{array}{l}\text { Time of dyeing (min) } \\
\text { Temperature of dyeing }\left({ }^{\circ} \mathrm{C}\right)\end{array}$ & \multicolumn{5}{c}{40,80} \\
\hline Conc. sulfuric acid (ml) & 19.9 & 19.4 & 18.7 & 17.8 & 17.0 \\
Emulsion (ml) & 0.5 & 1.0 & 1.7 & 2.7 & 3.4 \\
\hline
\end{tabular}
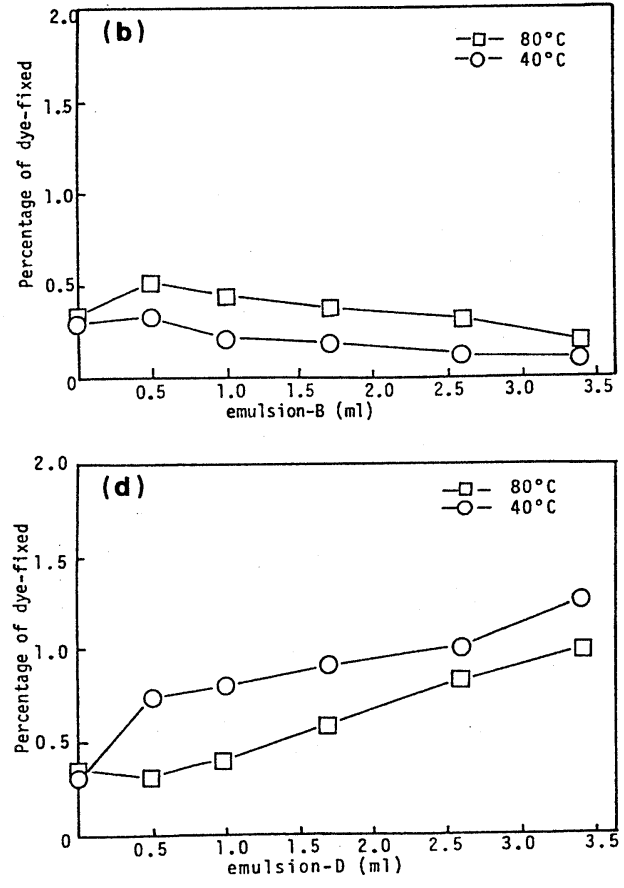

Fig.6 Effect of emulsions on C.I.Vat Violet $2 \mathrm{R}$ dyebath to polypropylene dyeing.
(a) emulsion-A
(b) emulsion-B
(c) emulsion-C
(d) emulsion-D 
さない。

(2) 例外もあるが, 高温染色では低温染色よりも, 染 着率が低い。

(3) 乳化液は, その量が多くなるほど, 助染効果が増 大市る。

カーボンの染色では, 高温染色が最適であったのに対 し, ポリプロピレンの染色では，低温染色が最適であるこ とは注目に值する。両者の相違は染浴組成が根本的に違う ためで, 染色剂や染浴組成の変化により最適な染色条件が
異なり,これらの要因の総合結果が鋭敏に，染色の色相・ 濃度・堅牢度などに反映するのは留意すべきである。

\section{5. 染色剂の固着状態11)}

\section{1 電子顕微鏡による解析}

Fig.7は, 染色試料を走査型の電子顕微鏡で撮影したも のである。写真は明らかに，試料に固着している染色剂 が，大小不規則に凝集しながら，表面を包被していること を示している。繊維の種類・形態，染色剤の種類・濃度な

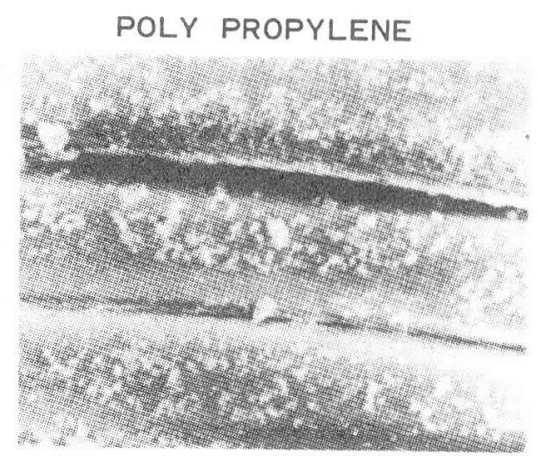

$40 \mu \mathrm{m}$

GLASS FILAMENT

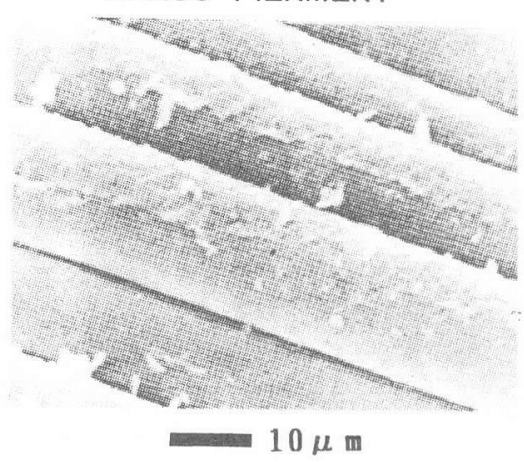

WOOL

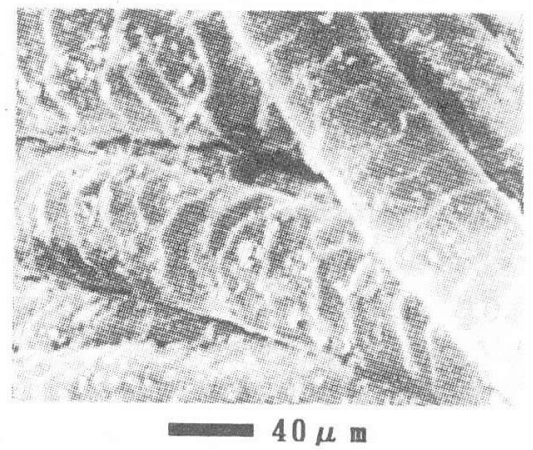

\section{POLY VINYLE CHLORIDE}

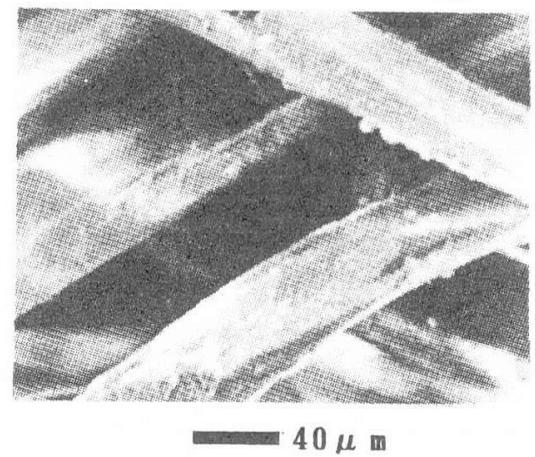

SARAN

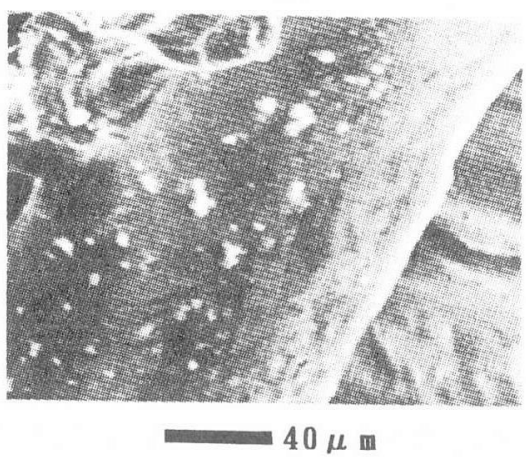

POLYESTER

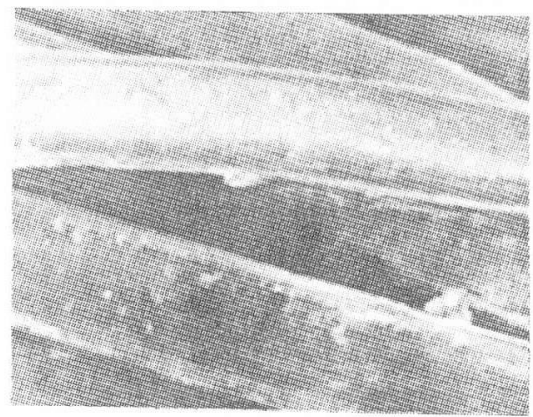

$40 \mu \mathrm{m}$

Fig.7 Fixed state of a coloring matter 
どによって, 粒子の形態・凝集形態・分散密度などは, そ れぞれ異なっている。たが，予想外に大きい粒子が数多く 見出される点では共通している。

染色剛が表面に重点的に凝集して固着するのは，濃い染 浴を用い，特に染斑ができやすい条件下で染色した結果に 基づくと思われる。また染色物の素材が結晶化した緊密な 組織で構成され，極性が低く，結晶間隙を開放しにくいた めに，染色剂分子の浸透が強く妨げられることも，鋭敏に 反映しているに相違ない。

Fig.7の写真は，染色試料の表面を走査したものに過ざ ない。したがって組織の内部に固着している染色剤の状態 は観察できないが，組織内部に拡散して固着している染色 剤の粒子は，はるかに微小で表面とは著しく異なると推察さ れる。これは発色機構が相違すると考えられるからである。

\section{2 染色刘の挙動}

硫酸染浴中では，染色剂は分子分散状態を保つ。これは 極性染料が染浴に溶解している状態と近似している。この 点では染浴は均染性を持つと言えよう。また硫酸は結晶化 度の高い非極性素材でも，軟化したり膨潤する。したがっ て染色剤分子は, 組織内部に搪散して固着する可能性が少 なくない。この過程では, 染色剂分子は比較的均一に分散 して固着するが，硫酸基がエステル状に結合しているた め, 特有の色相を示すに過ぎない。完全に発色させるに は，硫酸基を分離して酸化型に復元しなければならない。 この操作は，水またはアルカリからなる固着浴で行われ る。

染色物は，一時的に固着した染色剂・硫酸染浴を含んで いる。ここに残存する硫酸染浴は，固着浴に通入すると同 時に，水またはアルカリと作用して，急激に発熱する。発 熱量は莫大で強烈である。そのために, 染色剂分子は豊富 なエネルギーを得て励起し, 速やかに組織の内部に拡散す る。同時に硫酸基を放出して発色固着する。しかし，染色 物の発色は表層から内層に進展するので，ある程度の時間 が必要のようである。もちろん, 完全な発色は, 染色物の 素材・染色剂の種類などで異なり, しばしば酸化処理が必 要である。

\section{3 染着機構}

表面上に散在する大きい結晶粒子は，熱エネルギーで励 起された微結晶粒子の成長によって生まれたものである。 これには微結晶粒子の移行性の難易も密接に関連している のは当然である。大きい結晶粒子が表面に数多く見られる のは, 微結晶粒子の移行が容易であるためと考察すること ができる。素材の極性が低下するほど，このような現象が 明暸に現われることも，容易に理解できる。

極性の弱い素材の組織内には, 極性の強い液体が自由に 拡散や流動するのは許されない。この段階では, 硫酸の作
用によって結晶間隙が開放されていても，その状態を維持 し続けることができない。発熱による結晶組織の驰解も, 短時間の内に解消する。この条件下では, 開放した結晶組 織の間隙は, 容易に緻密な結晶組織に復元する。したがっ て拡散した染色剂分子は, 組織内部に閉し込められる。こ のようにして分散染着した微結晶粒子にも熱エネルギーが 与えられ, 移行性が高まり大きい結晶粒子に成長する機会 が与えられるが, 微小な結晶間隙に妨げられ, 自由に成長 はできない。微結晶粒子の成長は, 結晶間隙の大きさに支 配される。染色凨の染着状態に素材の結晶構造が強く反映 するのは，疑う余地がない。

\section{4 微結晶粒子の成長}

微結晶粒子の成長する確率が, 結晶間隙の大きさに支配 されるのは当然である。染色剤の染着状態に素材の結晶構 造が強く反映することも否定できない。組織内部の発色が 荤延して, 数多くの部分に微結晶粒子が染着していると推 定されるのは, 極性の低い素材の構造上の特徴に基づくと 言えよう。

結晶間隙の大きさは, 均一でなく大小が入り乱れている のが普通である。もし大きい間隙が存在すれば，微結晶粒 子は与えられた成長の機会を捉え，この間隙に移行するに 違いない。その結果, 大きい結晶粒子に凝集し, 分散密度 も不均一となる確率が高くなる。

硫酸基を放出して析出する微結晶粒子は，発生期状態の 分散染料としての特性を持つと考察される。難染性の素材 に対してもすぐれた染着力を表すのは，発生期状態の染色 剤に特有な性能である。このような機構の下に行われる染 色こそ最も本質的なもので，素晴らしい色相に発色する根 源であると言ってよい。

\section{5 素材の種類の影量}

微結晶粒子が組織の内部に安定に染着するか否かは, 素 材組織の包容力の優劣にも支配される。結晶化度が低く, 極性の高い素材は，包容力に富んでいる。そのために染色 剤分子が微結晶粒子となって析出し，そのまま安定な染着 状態を保ちやすい。一方, 結晶化度が高く極性を持たない 素材では，全く異なる現象が現れる。このような素材で は，表面染色を重点にした染着形態が支配的である。また 微結晶粒子の凝集による結晶粒子化が, 速かに行われる。

概して硫酸染浴を応用する難染性素材の染色では，染色 剂の定着状態は, 微結晶粒子の凝集に基づく結晶粒子化に 象徵される。組織内部に拡散して染着した微結晶粒子は, 凝集して結晶粒子になるのは容易ではない。弛解した素材 の組織が, 結晶化して緊密組織に復㷌するときには, 微結 晶粒子が表層に押し出されることも多い。これらの現象が 総合して, 表面で染着のおこる傾向が一層強まると推定さ れる。 


\section{6 染色堅牢度}

微結晶粒子から結晶粒子に成長すれば，染色剤の染着安 定度・堅牢度などに，無視できない影響をおよはすすのは明 らかである。この変化は, 耐光性や耐洗濯性の増加をもた らすが，一定限界を越えると耐摩擦性が減少する。一般に 染色物の耐摩擦性が不十分なのは, 染着した微結晶粒子が 過度に凝集したためと考えられる。

耐摩擦性を改善するには, 微結晶粒子の凝集作用を, 一 定の限界内に止めることが必要である。レジンフィニッシュ を併用すれば，耐摩擦性を改善するのに効果的である。

以上の観点を総合すれば，染色剂粒子の大きさ・分散密 度が，素材の種類によってそれぞれ異なることが理解でき る。ガラス織維の染色物に見られる染色剂の固着状態は, 表面包被の典型的なものである。素材の結晶構造に対応し て表面染着が大小さまざまに行われ，染色剂の定着状態も 多様な変化を示すと考えてよいのではなかろうか。

\section{6. 迅速染色法の応用}

\section{1 迅速染色法の特徵}

硫酸染浴を用いる迅速染色法を応用すれば，水不溶の非 極性染色剤を極性に変化させ, 分子溶液に移行させること ができる。フタロシアニンのように，無比の堅牢度を持つ 含金属高分子顔料も，分子溶液として利用することが可能 となる。これらの分子は, 結晶組織や層状組織の間隙に浸 透して結晶化し, 安定な染着状態を形成する。堅固な結晶 組織で構成される難染性物質も，その種類・構造に関係な く，短時間で染色できる特徴がある。染着作用が極めて強 烈で, 染色は瞬間的に終了する。染着は表面に限定され, 染着量も少ないが, 染着剤の特有な色相・性質は強く反映 される。

従来, 染色の手段が皆無であるとされていたカーボン. 石英・ガラスなども, 容易に染色することができる。しか し, 染色の対象が表面に限られるために, 表面積・比表面 積などの小さい素材の染色には, 応用が困難である。染色 の対象としては, 小粒子径の粉状物質が好適である。カー ボンと膠を主成分とする墨に, 染色カーボンを応用すれ ば，墨色を希望の色相に変化でき，中国の古墨に匹敵する 青光を反映する製墨も容易である。

\section{2 染色条件の選定}

プロピレンに代表される, 炭化水素で構成され, 染色の 対象となる官能基も染着座席も有さない難染性合成緎維類 も, 迅速染色が可能である。ナイロン・ビニロンのよう に, 硫酸染浴の作用で軟化や溶解する素材は, 硫酸の濃度 ・染色温度を可能な限り低くして, 染色時間を1分以内に 限定する迅速染色方式が必要である。染色の対象となる素 材の耐酸性に応じて, 染浴組成・温度・染色時間を最適と
なるように調整することは，すぐれた染色結果を得るため の必須条件である。

過熱蒸気による熱固定，レジンフィニッシュなどは，酎 摩擦性の改善に，著しく寄与する。

染色剂の選択も，染色結果に大きな影響を与える。染着 は専ら染色剂の強大な染着力によって支配され，染色され る素材の影響は極めて少ない。したがって, 染着形態・色 相・堅审度などが，染色剂の優劣によって異なってくる。 堅牢色に染色するには, 無比の堅审度と優美な色相を併有 し, 強大な染着力を持つ染色剂を用いることが肝要である。

硫酸は，染色剂を分子溶液にすると同時に，急激な染着 作用を発現させるため用いるものである。この染浴は，異 常に強い酸性となる。この染法に準拠して, 高濃度の無機 酸または有機酸で組成される染浴を用いて染色すれば，表 面染色を重点とする迅速染色を行うことができよう。完全 な染着・発色は, 熱固定・レジンフィニッシュなどの後処 理で行えばよい。

\section{3 染色の新機軸}

染色剤の硫酸溶液を中和して得られるコロイドの利用も 新機軸の開発に役立つと思われる。無比の堅牢染色を行う ために，含金属高分子顔料・縮合多環高分子染料などを効 果的に活用し, そのコロイドと固着剤で組成される染浴を 用い,プリント・パッティングなどを行うならば，染色の 新しい分野が開けるに相違ない。

迅速染色法の欠点は, 濃硫酸による危険と障害を伴うこ とである。この欠点を解消する手段として, 水溶性のイン ジゴゾール・アンスラゾールなどの染料を用い, 迅速染色 を行うのが効果的である。硫酸のもつ結晶組織の開放作用 は，非イオン活性剤と有機塩基を混和した乳化剂で代用す ればよい。試染の結果 ${ }^{12}$ は, この考察が正しいことを示し ている。

カーボンのように, 緻密で強勒な結晶構造を持つ難染性 素材は, 染色剂を気相状態やイオンの状態にして, 結晶間 陌を自由に流動できるような条件下で染色すれば，更に本 質的に強固な染着と, 完全な発色を得ることが期待できそ うである。

\section{4 羊毛の連続染色}

酎酸性に富む羊毛は, 迅速染色の対象として好適であ る。洗浄工程を経た脂付羊毛は, 稀硫酸液中に通入した 後, 炭化を行って植物質を除去する。炭化した羊毛には, 濃樎された硫酸が含まれている。この羊毛を分子分散状態 を保つ高温染浴に通入すれば, 迅速染色法に酷似した染色 結果を得ることが期待される。完全な染着と発色は, 蒸熱 処理によって行えばよい。

この染色方式 ${ }^{13)}$ 応用すれば，炭化した羊毛をアルカリ 液で中和する工程が不要となる。乾燥工程で消費する熱量 
(a)

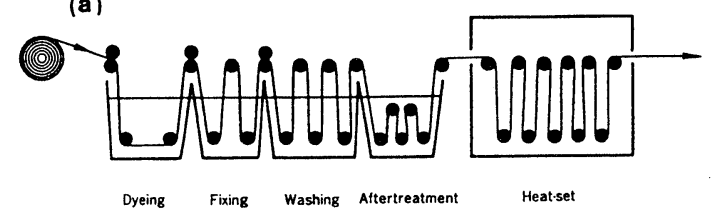

(b)

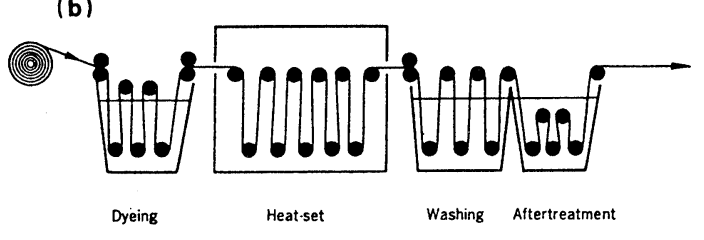

Fig.8 New processes for quick dyeing with sulfuric $\operatorname{acid(a)~and~without~sulfuric~} \operatorname{acid}(b)$.

も皆無になる。また洗浄・炭化・染色を流れ作業で連続的 に行うことができる。したがって，作業能率が著しく向上 し, 大幅な経費の節約となる。羊毛の染色加工に迅速染色 法を応用するのは，有意義ではなかろうか。

\section{5 迅速染色法の工程}

Fig.8-(a),(b)は, 迅速染色法の代表的な工程を例示したも のである。

(a)は, 硫酸染浴を用いて染色した後, 固着浴で処理し て発色を完成させる, 難染性素材を染色する標準工程を示 している。

(b)は, 硫酸を使用せずに, 染色剂のコロイド液と, 固 着剂とを混合した染浴を用い, 素材を染色した後, 均一に 脱液し熱固定を行ない, 染着を完成させる標準工程であ る。

熱固定は，蒸熱処理と乾熱処理に代表される。蒸熱処理

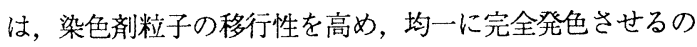
に効果的である。しかし, 蒸熱処理により染色剂粒子を移 行させるには一定の限界がある。応用する染色剂は, この 限界内に止まるものを選ばなければならない。移行性が高 く, 蒸熱処理によってはなはたしく流動する染色剤は, こ の迅速染色方式には不適である。

乾熱処理は，低重合度の固着剂を高重合化合物に変化さ せ，硬化させるために行う。混合するレジンの特性に応じ て，乾熱処理の温度・時間を適切にして行えば，優美な堅 牢色に染着することができる。

熱固定が終れば洗浄浴に通入し，不用な付着物を完全に 除去する。この工程では, 不安定な状態をしている染色剂 や助剂が完全に除かれる。後処理浴では，必要な加工を 行った後, 乾燥されて染色工程が終了する。

ここに紹介した迅速染色法を工業的に応用するには，な お研究を要する問題が多く残されている。染浴の循環や調
整, 染色剂・助剤の補給・排液処理などの問題を解決しな ければならない。しかし，現在まで染色が不可能であると されている極難染性の素材でも, 容易に染色できるのは, この新しい迅速染色法の特記に值する効用である。

\section{文献}

1) 外狩素心庵, 唐墨和墨図説 (1953) 美術出版社.

2) 宮坂和雄, 共立女子大学紀要 7号(1961).

宮坂和雄, 高分子 15 (No.168) (1966) 209.

宮坂和雄, 科学朝日 1974 (4) 100.

宮坂和雄, 繊維と工業 30 (1974) 292.

宮坂和雄, 化学 30 (2) (1975) 128.

3) E.Valko, Kolloid-chemische Grundlagen der Textileveredlung (1937) p.393, Julis Springer.

M.R.Fox, Vat Dyestuff and Vat Dyeing (1948) p.57, Chapman \& Hall.

H.A.Rutherford, The Application of Vat Dyes (1953) p.13, AATCC Monograph.

T.Vickerstaff, Phisical Chemistry of Dyeing(1954) p.87, Imp. Chem. Col.

Faradey Soc., The Phisical Chemistry of Dyeing and Tanning (1954) p.30.

宮坂和雄, 家庭科学, 52 (1985) 10 .

4) 宮坂和雄, 日本特許公告 昭47-013473.

宮坂和雄, 日本特許公告 昭48-4919.

宮坂和雄, 日本特許公告 昭49-12877.

K.Miyasaka, U.S.A. Patent 3652200 (1972).

K.Miyasaka, British Patent 1259909 (1972).

宮坂和雄, 共立女子大学紀要 25号(1978).

5) U.Hofmann and A.Frenzel, Z.Elektro-chem. 40 (1934) 511.

赤松秀雄, J. Colloid Science 2 (1949) 593. カーボンブラック便覧 (1971) p.166, 図書出版.

6) Colour Index (1927) Soc.Dyes \& Colourists.

7) 宮坂和雄, 共立女子大学紀要 11号(1964).

宮坂和雄, 共立女子大学紀要 20号(1974).

8) カーボンブラック便覧 (1971) p.110, 図書出版.

9) L.Disenrens, The Chemical Technology of Dyeing and Printing (1948)p.119, Reinhold Publishing Co. 宮坂和雄, 染色学 (1950) p.89, 恒春閣.

10) 宮坂和雄, 共立女子大学紀要 26号(1979).

11）宮坂和雄, 共立女子大学紀要 25 号(1978).

12）宮坂和雄, 未発表 (1980).

13）宮坂和雄, 日本特許公告 昭18-2149.

C.L.Bird, The Theory and Practice of Wool Dyeing (1951) p.36, Soc.Dyers \& Colourists. 